\title{
Pelatihan Sistem Informasi Desa untuk Meningkatkan Kemampuan Literasi Digital Perangkat Desa Taman Sari
}

\author{
Mugi Praseptiawan ${ }^{1}$, Eko Dwi Nugroho ${ }^{2}$, Amirul lqbal $^{3}$ \\ 1, 2, 3 Institut Teknologi Sumatera \\ Email: mugi.praseptiawan@if.itera.ac.id, (0721) 8030189)
}

\begin{abstract}
ABSTRAK
Kemampuan literasi digital perangkat desa merupakan aspek yang paling utama dalam mendukung pelayanan kepada masyarakat. Implementasi sistem informasi desa merupakan bagian kebijakan Pemerintah Provinsi Lampung untuk penerapan smart village. Aplikasi sistem informasi desa yang dikembangkan secara mandiri oleh Pemerintah Desa Taman Sari dan Program Studi Teknik Informatika belum berjalan optimal, hal ini karena perangkat desa belum memahami penggunaan Sistem Informasi Desa. Pelatihan penggunaan sistem informasi desa dengan platform OpenSID dibutuhkan oleh perangkat desa untuk meningkatkan kemampuan literasi digital perangkat desa. Kegiatan pengabdian masyarakat ini bertujuan untuk meningkatkan kemampuan literasi digital perangkat desa Taman Sari yang merupakan desa binaan Program Studi Teknik Informatika Institut Teknologi Sumatera. Metode yang digunakan adalah dengan metode pelatihan dan tutorial yang dilakukan dengan 3 tahapan, yaitu 1) persiapan, 2)Pelaksanaan, dan 3) Evaluasi. Hasil kegiatan pelatihan sistem informasi desa perangkat desa taman sari. Hasil dari pelatihan desa Taman Sari menghasilkan peningkatan keterampilan dan pengetahuan perangkat desa setelah mengikuti seluruh rangkaian materi yang diberikan. Rekomendasi kegiatan disarankan untuk segera mengambil tindakan yang lebih konkrit berupa implementasi kegiatan penerapan sistem informasi desa dengan mendorong dikeluarkannya Peraturan Desa Taman Sari tentang penerapan sistem informasi desa.
\end{abstract}

Kata kunci: Literasi digital, OpenSID, Smart Village

\begin{abstract}
The digital literacy capability of village devices is the most important aspect in supporting services to the community. The implementation of village information system is part of lampung provincial government policy for smart village implementation. The application of village information system developed independently by taman sari village government and Informatics Engineering Study Program has not been running optimally, this is because the village device has not understood the use of Village Information System. Training on the use of village information systems with the OpenSID platform is needed by village devices to improve the digital literacy capabilities of village devices. This community service activity aims to improve the digital literacy capability of Taman Sari village device which is a village assisted by the Informatics Engineering Study Program of the Sumatra Institute of Technology. The method used is by training methods and tutorials conducted with 3 stages, namely 1) preparation, 2)Implementation, and 3) Evaluation. The results of village information system training activities taman sari village device. The result of taman sari village training resulted in improved skills and knowledge of village devices after following the whole series of materials provided. Activity recommendations are advised to immediately take more concrete actions in the form of implementation of village information system implementation activities by encouraging the issuance of Taman Sari Village Regulation on the application of village information systems.
\end{abstract}

Keywords: Digital Literacy, OpenSID, Smart Village

\section{PENDAHULUAN}

Undang-undang nomor 6 Tahun 2014 pasal 86 tentang Sistem Informasi Pembangunan Desa dan Pembangunan Kawasan Perdesaan. Pada bagian ketiga Pasal 86 UU Perdesaan tentang Sistem Informasi Pembangunan Perdesaan dan Pembangunan Perdesaan disebutkan bahwa desa berhak mengakses informasi melalui sistem informasi yang dikembangkan oleh 
pemerintah kabupaten atau kota. Implementasi undang-undang tersebut diturunkan dalam peraturan Gubernur Lampung nomor 36 tahun 2020 yang mengatur tentang pelaksanaan smart village di provinsi lampung tahun 2020-2024.

Sistem Informasi Desa merupakan perangkat pendukung yang dirancang untuk mendukung peran masyarakat dalam mengelola sumber daya dan potensinya pada tingkat desa. Sistem informasi desa terdiri dari beberapa bagian, yaitu kumpulan perangkat sosial dan perangkat teknologi informasi, yang dikelola dalam dinamika kehidupan masyarakat atau masyarakat di tingkat desa. Sebagai suatu sistem informasi, data dan informasi merupakan isi atau isi, dan merupakan muatan utama yang dikelola dalam sistem informasi desa. (Hermansyah, 2015), penerapan sistem indormasi desa bertujuan untuk mempermudah semua unit dalam organisasi dalam menyampaikan informasi secara teratur, mudah dan terpercaya. Dengan perkembangan teknologi, penggunaan perangkat teknologi informasi dalam kegiatan pelayanan maupun sub kegiatan akan membantu mendorong proses pelayanan secara lebih efektif dan efektif (Kurnianingsih et al., 2020).

Pesatnya perkembangan teknologi dan dukungan jaringan telekomunikasi yang baik di Desa Taman Sari Kacamatan Ketapang yang memungkinkan untuk dibangunnya sistem informasi berbasis web untuk mendukung penyediaan informasi kepada seluruh warga desa, khususnya dari para pemimpin desa hingga ke masyarakat. Sistem informasi pedesaan akan memperpendek jarak dan waktu penyediaan informasi dan pengelolaan penduduk. Warga dapat langsung mengakses semua informasi yang terkait dengan desa, dan semua dokumen serta formulir dapat diunduh pada halaman sistem informasi desa (Herpendi, 2017).

Perangkat desa membutuhkan alat atau perangkat teknologi informasi untuk mengkoordinasikan dan merencanakan sumber daya yang dimilikinya, di mana alat yang dapat membantu perencanaan, koordinasi, dan komunikasi antara pemerintah desa dan masyarakat (Wahyudi et al., 2019). Selain itu, perangkat desa juga perlu perlu menguasai literasi digital, dimana hasil penelitian dengan perlakuan eksperimen melalui kelas kontrol dapat meningkatkan keterampilan literasi teknologi informasi peserta pelatihan(Praseptiawan et al., 2019).

Berdasarkan uraian di atas, penting bahwa keterampilan dan pengetahuan perangkat desa dalam implementasi smart village sangat diperlukan sehingga mendukung kebijakan pemerintah dalam penerapan smart village. Adapun tujuan pelatihan ini adalah meningkatkan keterampilan dan pengetahuan perangkat desa dalam penggunaan sistem informasi, selain itu juga berdampak positif terhadap kemampuan literasi digital perangkat desa. Oleh karena itu, tawaran solusi ini merupakan bentuk pengabdian dari program pengabdian kepada masyarakat yang dilaksanakan oleh Tim Dosen Institut Teknologi Sumatera.

\section{BAHAN DAN METODE}

Jenis pengabdian masyarakat adalah melakukan pelatihan yang dirancang dalam bentuk praktik terkait penggunan sistem informasi desa, tempat pelaksanaan pelatihan dilakukan di Aula Desa Taman Sari. Pelaksanaan kegiatan dilakukan pada tanggal 12 April 2021 pukul 08.00 sampai dengan 15.00 WIB. Peserta pelatihan terdiri dari 30 orang perangkat desa dan masyarakat. Perangkat Desa yang mengikuti pelatihan sistem informasi desa ini adalah perangkat desa yang sudah lama didampingi oleh Kepala Desa Taman Sari.

Metode pelatihan dilakukan dengan 3 tahapan, yaitu 1) persiapan, 2)Pelaksanaan, dan 3) Evaluasi : 


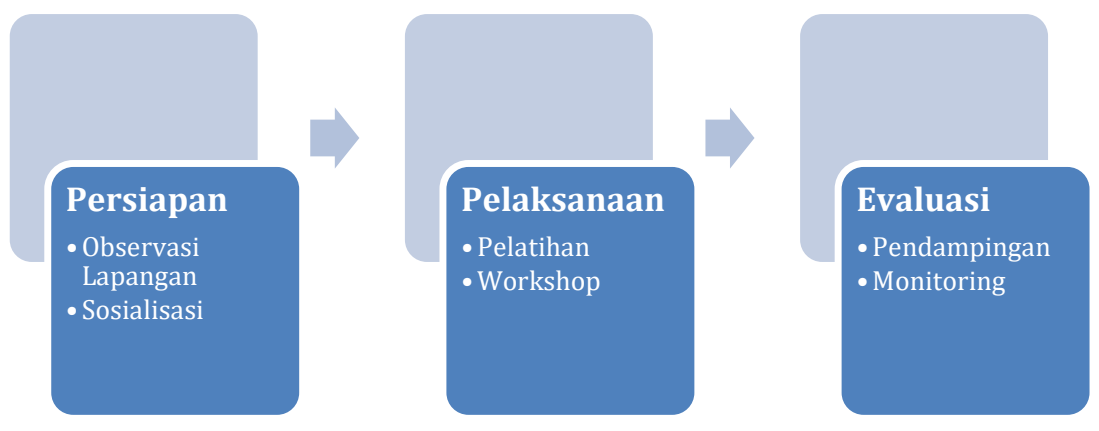

\section{Persiapan}

Gambar 1 Tahapan Kegiatan

Persiapan dilakukan dengan observasi lapangan dan mencari informasi permasalahan pemerintah Desa Taman Sari dan sosilisasi kegiatan terkait program pengabdian masyarakat dan memberikan tambahan pengetahuan kepada masyarakat tentang penggunaan perangkat teknlogi informasi dalam mendukung pelayanan kepada masyarakat.

\section{Pelaksanaan}

Kegitan ini adalah kegiatan partisipasi peragkat desa dan masyarakat yakni pembelajaran bersama-sama dimana seluruh perangkat desa dan masyarakat yang terlibat dalam kegiatan program langsung praktek untuk menggunakan sistem informasi desa. Dalam kegiatan ini perangkat desa dan masyarakat dibimbing secara langsung oleh tim pelaksana dalam penggunaan sistem informasi desa.

\section{Evaluasi}

Dalam kegiatan ini dilakukan pendampingan penerapan sistem informasi desa untuk pelayanan kepada masyarakat. Dalam kegiatan ini masyarakat didampingi oleh tim pelaksana melakukan demonstrasi dan penerapan sistem informasi desa. Dalam monitoring ini juga dilihat bagaimana potensi keberlanjutan program yang dilakukan.

Strategi kegiatan pengabdian ini dilakukan melalui kerjasama antara Lembaga Penelitian dan Pengabdian kepada Masyarakat (LP3) ITERA dan Desa Taman Sari. Pengabdian kepada masyarakat ini dirancang dalam bentuk pelatihan yaitu penggunaan sistem informasi desa, kebijakan perangkat Desa Taman Sari di Kabupaten Lampung Selatan (Gambar 1). Tujuan dari pelatihan ini adalah untuk meningkatkan kapasitas berupa keterampilan dan pengetahuan dalam penggunaan sistem informasi desa, khususnya yang terkait dengan isu peningkatan literasi digital.

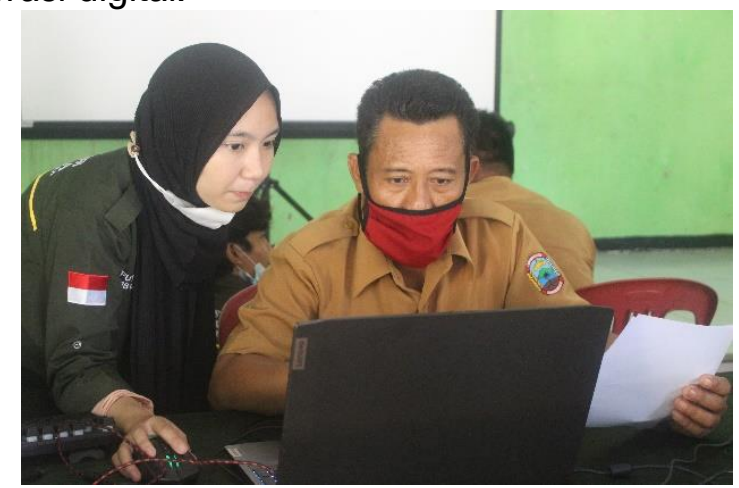

(a)

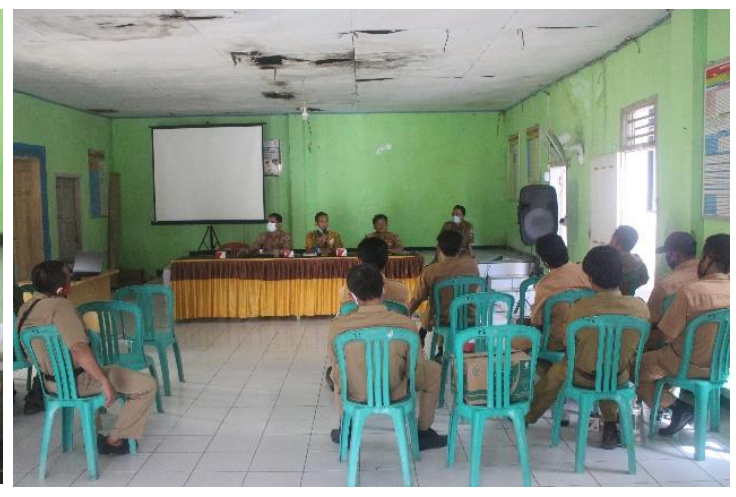

(b) 

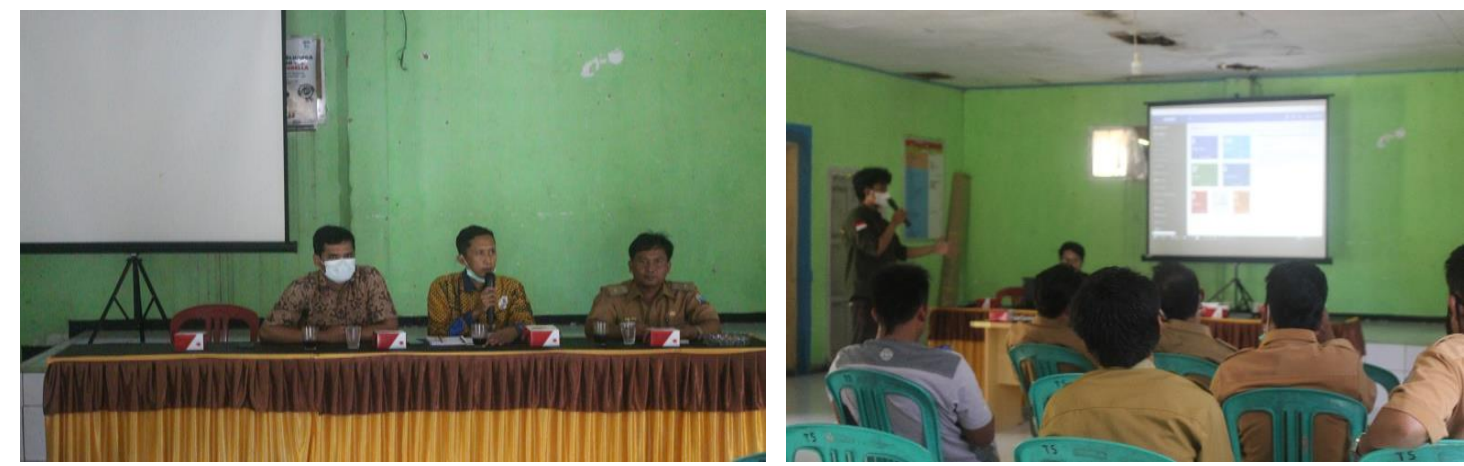

(c)

Gambar 2 (a) Kegiatan pelatihan Sistem Informasi Desa, (b) Brainstorming Literasi Digital,

(c) Penyampaian rencana kebijakan Sistem Informasi Desa

Penyampaian materi pelatihan dibagi menjadi dua sesi yaitu (1) materi hari pertama yang berisi pengetahuan yang meliputi: kebijakan dan program pemerintah Provinsi Lampung tentang Smart Village, konsep dan praktik sistem informasi desa, serta pentingnya literasi digital; (2) Pada sesi kedua, materi berupa tutorial cara melakukan teknis penggunaan sistem informasi desa yang dipandu oleh mahasiswa teknik informatika,. Semua materi pelatihan disampaikan oleh narasumber dari Jurusan Teknologi Produksi dan dan industri Institut Teknologi Sumatera. Tim Pengabdian Teknik informatika ITERA yang terdiri dari lima dosen dan 5 mahasiswa. Data primer diperoleh melalui wawancara dan observasi dan data sekunder diperoleh melalui penelusuran dokumen resmi pemerintah provinsi lampung tentang kebijakan smart village dengan menggunakan sistem informasi desa. Proses wawancara dilakukan dengan informan kepala desa Taman sari yang hadir sebagai narasumber.

Untuk mengetahui efektifitas pelatihan dilakukan evaluasi yang tercermin dalam bentuk pretest dan post-test peserta di awal dan akhir pelatihan. Evaluasi peserta pelatihan dilakukan dengan terlebih dahulu menentukan indikator pengukuran kapasitas pengetahuan perangkat desa terhadap materi yang disampaikan. Indikator untuk mengukur kapasitas pengetahuan dimulai dari mengetahui, cukup mengetahui dan tidak mengetahui. Teknik pengumpulan data indikator kapasitas pengetahuan peserta dilakukan dengan menyebarkan kuesioner kepada peserta didampingi oleh fasilitator.

\section{HASIL}

Hasil dari kegiatan pengabdian masyarakat "Pelatihan Penggunaan Website Sistem Infomasi Desa untuk Menunjang Pelayanan Administrasi yang Efektif di Desa Taman Sari" adalah tersedianya platform sistem informasi desa, pengelolaan dan pemanfaatan sistem informasi desa untuk pelayanan kepada masyarakat. Selain itu, pelatihan perangkat desa Taman Sari menghasilkan peningkatan keterampilan dan pengetahuan perangkat desa setelah mengikuti seluruh rangkaian materi yang diberikan. Rekomendasi kegiatan disarankan untuk segera mengambil tindakan yang lebih konkrit berupa implementasi kegiatan penerapan sistem informasi desa dengan mendorong dikeluarkannya Peraturan Desa Taman Sari tentang penerapan sistem informasi desa sebagai turunan dari kebijakan program smart village Pemerintah Provinsi Lampung.

\section{PEMBAHASAN}

Sesuai dari hasil kegiatan pengabdian masyarakat masyarakat "Pelatihan Penggunaan Website Sistem Infomasi Desa untuk Menunjang Pelayanan Administrasi yang Efektif di Desa Taman Sari". Pembahasan dilakukan pada 1) Platform sistem informasi desa, 2) Pelatihan perangkat desa Taman Sari, 3). Pengelolaan dan pemanfaatan sistem informasi desa. 


\section{Platform sistem informasi desa}

Sistem informasi desa yang digunakan oleh desa Taman Sari menggunkan OpenSID, dimana OpenSID adalah platform terbuka yang berisi source code dan database sistem informasi desa yang dikembangkan secara besama-sama oleh komunitas dan relawan masyarakat yang peduli dalam pengembangan sistem informasi desa. Karena bersifat terbuka, masyarakat dan komunitas dapat memanfaatkan dan saling berkontribusi dalam pengembangan sistem informasi yang dapat bermanfaat bagi masyarakat desa.

Platform OpenSID dipilih untuk digunakan dalam pengembangan sistem informasi desa adalah karena kemudahan dalam penggunaan dan dukungan relawan, komunitas dan pengembang yang tersebar di seluruh wilayah Indonesia. Berikut adalah hasil implementasi sistem informasi desa Taman Sari dengan OpenSID.

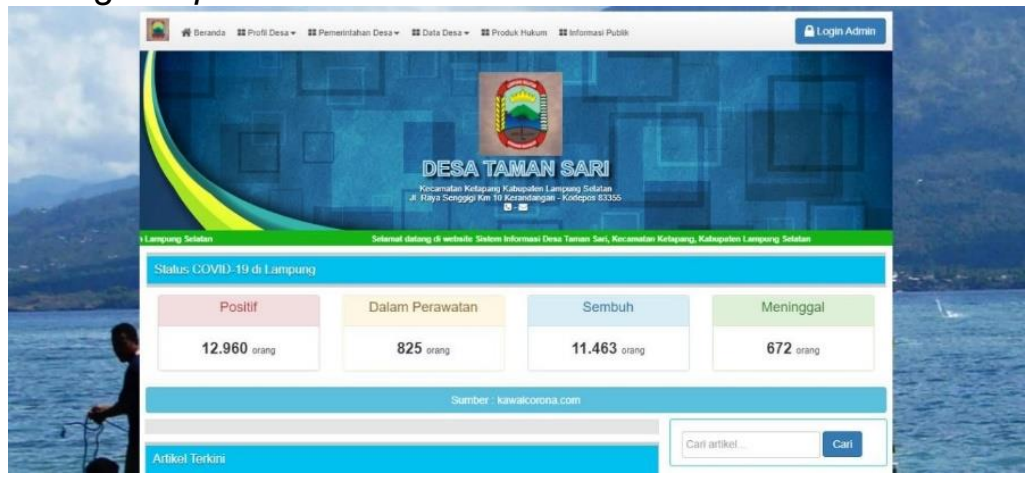

(a)

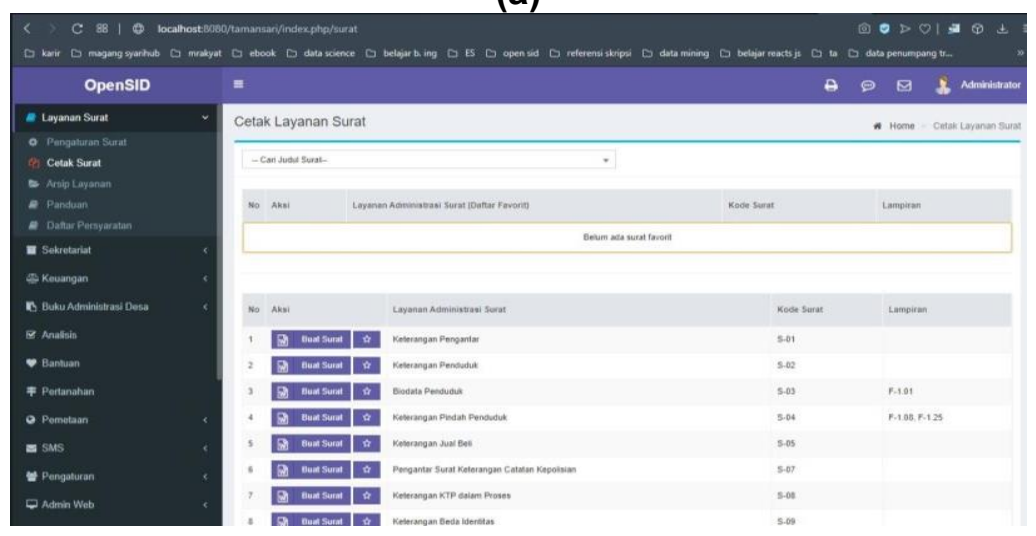

(b)

Gambar 3 (a) Laman website OpenSID desan Taman Sari, (b) Fitur laman pelayanan Sistem Informasi Desa dengan OpenSID

\section{Pelatihan perangkat desa Taman Sari}

Selain pengembangan sistem informasi desa, tim pengabdian juga memberikan pelatihan pengelolaan sistem informasi desa bagi perangkat desa serta masyarakat Desa Taman Sari yang bertujuan agar nantinya Desa Taman Sari memiliki sumber daya manusia yang mampu mengelola keberadaan sistem informasi yang mandiri. Selain itu, pelatihan juga digunakan untuk meningkatkan keterampilan dan pengetahuan masyarakat dalam memahami era digital. Adapun hasil kegiatan pelatihan diukur berdasarkan indikator dan pemahaman masyarakat sebagai berikut pada tabel 1 .

Efektivitas pelatihan juga dipengaruhi oleh beberapa faktor, baik faktor pendukung maupun faktor penghambat. Faktor pendukung pelatihan yang ditemukan dalam pengabdian ini adalah antusiasme dan harapan yang tinggi dari para peserta untuk mengikuti kegiatan tersebut. Sehingga ketertarikan tersebut dapat memudahkan para narasumber untuk mengembangkan kapasitas masing-masing peserta pelatihan. Selain itu, diketahui juga bahwa ada faktor penghambat yang perlu diantisipasi saat melakukan kegiatan serupa di kemudian hari. Faktor 
penghambatnya adalah materi yang lebih teknis tidak bisa dilaksanakan, seperti dalam bentuk tutorial untuk peserta. Ini penting karena kegiatan tutorial yang lebih teknis pada dasarnya dapat meningkatkan keterampilan praktis yang seharusnya dimiliki perangkat desa dalam dalam pemanfaatan sistem informasi desa untuk pelayanan kepada masyarakat.

Tabel 1. Rekapitulasi kapasitas peserta pada pre-test dan post-test terhadap materi pelatihan dan kemampuan literasi digital

\begin{tabular}{|c|c|c|c|c|c|c|c|}
\hline \multirow{3}{*}{ No } & \multirow{3}{*}{$\begin{array}{l}\text { Materi Pelatihan Sistem } \\
\text { Informasi Desa }\end{array}$} & \multicolumn{6}{|c|}{ Indikator Perubahan Kapasitas (Respon Peserta) } \\
\hline & & \multicolumn{2}{|c|}{ Mengetahui } & \multicolumn{2}{|c|}{ Cukup Mengetahui } & \multicolumn{2}{|c|}{ Tidak mengetahui } \\
\hline & & $\begin{array}{l}\text { Pre- } \\
\text { Test }\end{array}$ & Post-Test & $\begin{array}{l}\text { Pre- } \\
\text { Test }\end{array}$ & Post-Test & $\begin{array}{l}\text { Pre- } \\
\text { Test }\end{array}$ & Post-Test \\
\hline 1 & $\begin{array}{l}\text { Kebijakan dan Program } \\
\text { Smart Village }\end{array}$ & $7 \%$ & $81 \%$ & $40 \%$ & $19 \%$ & $53 \%$ & $0 \%$ \\
\hline 2 & $\begin{array}{l}\text { Konsep dan Praktik Sistem } \\
\text { Informasi Desa }\end{array}$ & $9 \%$ & $93 \%$ & $31 \%$ & $7 \%$ & $60 \%$ & $0 \%$ \\
\hline 3 & Pentingnya Literasi Digital & $60 \%$ & $86 \%$ & $40 \%$ & $14 \%$ & $0 \%$ & $0 \%$ \\
\hline 4 & $\begin{array}{l}\text { Praktek Teknik Penggunaan } \\
\text { Sistem Informasi Desa }\end{array}$ & $10 \%$ & $77 \%$ & $19 \%$ & $23 \%$ & $71 \%$ & $0 \%$ \\
\hline & Rata-rata & $21,5 \%$ & 84,25 & $32,5 \%$ & $15,75 \%$ & $46 \%$ & $0 \%$ \\
\hline
\end{tabular}

Tabel 1 di atas ini menunjukkan bahwa tujuan utama dari pelatihan sistem informasi desa ini untuk meningkatkan pemahaman dan pengetahuan peserta terhadap berbagai materi pelatihan yang disajikan. Seperti terlihat pada tabel, bahwa dari 30 peserta indikator yang mengetahui materi, hanya rata-rata $21,5 \%$ yang tidak disajikan pada saat itu. Kemudian meningkat menjadi rata-rata $84,25 \%$ dari peserta yang sudah memahami dan mengetahui materi terkait sistem informasi desa. Artinya, peserta yang awalnya cukup tahu dan tidak mengetahui materi sistem informasi desa mengalami penurunan yang cukup signifikan. Dengan demikian, dapat disimpulkan bahwa hasil pengukuran keefektifan pelatihan sudah sangat berhasil dalam mencapai tujuannya.

\section{Pengelolaan dan pemanfaatan sistem informasi desa}

Kegiatan pengelolaan dan pemannfaatan sistem inormasi adalah kegiatan lanjutan dari pelatihan, dimana pihak desa dilakukan pendampingan dan monitoring yang dilakukan oleh Tim pelaksana Pengabdian Masyarakat. Adapun tujuan kegiatan ini adalah untuk melihat penggunaan sistem informasi apakah sudah dimanfaatkan denngan baik atau belum. Dalam kegiatan ini masih ditemukan beberapa masalah ketersediaan data kepedudukan. Mitra masih ragu-ragu dalam melakukan proses input data kependudukan. Kondisi ini pada berdampak pada kelengkapan data pendudukan. Untuk mengatasi masalah ini tim pelaksana melakukan penjelasan kembali dan melakukan update data kependudukan yang dibandingkan dengan data dinas catatan sipil. 


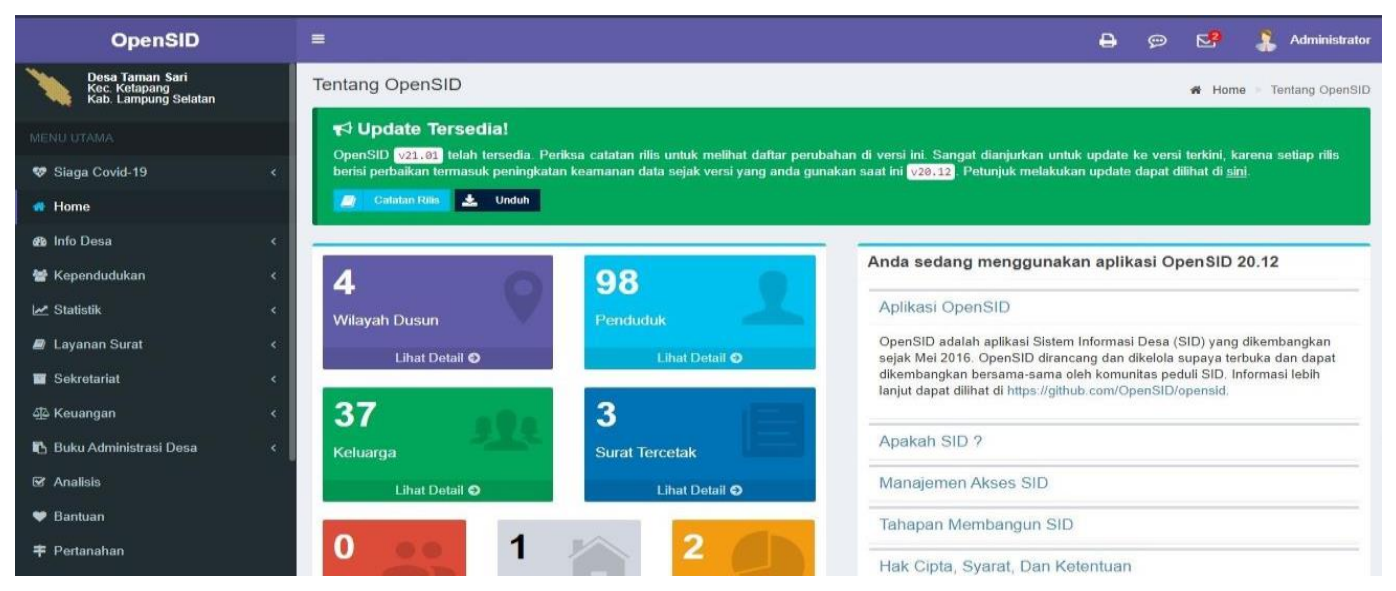

Gambar 4 (a) Dasboard pengelolaan sistem informasi Desa Taman Sari

Gambar 4 merupakan hasil pengelolaan dan pemanfaatan sistem informasi desa yang tersaji pada halaman admin sistem informasi desa Taman Sari Kecamatan Ketapang Kabupaten Lampung Selatan.

\section{KESIMPULAN DAN SARAN}

Kesimpulan pada pengabdian kepada masyarakat ini adalah aplikasi sistem informasi berbasis web dengan platform OpenSID dapat di terapkan di Desa Taman Sari. Selain itu pelatihan yang diadakan di Desa Taman Sari membuat perangkat desa dapat berjalan efektif yang didapat dari indikator penilaian pre-test dan post-test perangkat desa yang menunjukan meningkat, dari pemahaman dan pengetahuan peserta terhadap berbagai materi pelatihan yang disajikan. Hasil pengukuran menunjukan indikator yang mengetahui materi, hanya ratarata $21,5 \%$ yang tidak disajikan pada saat itu, kemudian meningkat menjadi rata-rata $84,25 \%$ dari peserta yang sudah memahami dan mengetahui materi terkait sistem informasi. Dari peningkatan pemahaman perangkat desa, menunjukan meningkatnya kemampuan literasi digital peserta pelatihan. Rekomendasi kegiatan disarankan untuk segera mengambil tindakan yang lebih konkrit berupa implementasi kegiatan penerapan sistem informasi desa dengan mendorong dikeluarkannya Peraturan Desa Taman Sari tentang penerapan sistem informasi desa.

\section{UCAPAN TERIMA KASIH}

Ucapan terima kasih kami berikan kepada Lembaga Penelitian dan Pengabdina Masyarakat dan Penjaminan Mutu Pendidikan (LP3) Institut Teknologi Sumatera (ITERA), Desa Taman Sari yang mendukung sepenuhnya terhadap pengabdian kepada masyarakat. Ucapan terima kasih juga kami berikan kepada Himpunan Mahasiswa Teknik Informatika ITERA yang membantu dalam pelaksanaan pengabdian kepada masyarakat.

\section{DAFTAR PUSTAKA}

Hermansyah. (2015). Peran Kepala Desa Dalam Pelaksanaan Pembangunan

Kecamatan Tana Lia Kabupaten Tana Tidung. EJournal Pemerintahan Integratif, 53(9), 1689-1699.

Herpendi, H. (2017). Sistem Informasi Desa di Kecamatan Takisung. Jurnal Sains Dan Informatika, 3(2), 76-82. https://doi.org/10.34128/jsi.v3i2.103

Kurnianingsih, I., Yugaswara, H., Suhaeri, Wardinoyo, \& Rosini. (2020). PKM Smart 
Village Melalui Pengelolaan Perpustakaan Desa Rintisan Berbasis Teknologi Informasi Di Desa Bantarsari Bogor. ABDINUS: Jurnal Pengabdian Nusantara, 4(1), 63-74.

Praseptiawan, M., Siswanto, P., \& Afrida, T. (2019). Digital Library Development and Evaluation to Improve Students' Digital Literacy. Journal of Physics: Conference Series, 1179(1). https://doi.org/10.1088/1742-6596/1179/1/012042

Wahyudi, A., Ngumar, S., \& Suryono, B. (2019). Faktor-Faktor Yang Mempengaruhi Kinerja Manajerial Perangkat Desa (Studi Pada Perangkat Desa Di Kabupaten Sumbawa). Jurnal Riset Akuntansi Mercu Buana, 5(2), 111.

https://doi.org/10.26486/jramb.v5i2.815 